\title{
Polyphenols, Carotenoids, Vitamin C Content in Tropical Fruits and Vegetables and Impact of Processing Methods
}

\author{
Emy Njoh Ellong, Corinne Billard, Sandra Adenet*, Katia Rochefort \\ Pôle Agroalimentaire Régional de Martinique (P.A.R.M.), Habitation Petit Morne No 37597232 Le Lamentin, \\ Martinique, France \\ Email: $\underline{\text { adenet@parm.asso.fr }}$
}

Received 13 February 2015; accepted 3 March 2015; published 9 March 2015

Copyright (C) 2015 by authors and Scientific Research Publishing Inc.

This work is licensed under the Creative Commons Attribution International License (CC BY).

http://creativecommons.org/licenses/by/4.0/

(c) (i) Open Access

\section{Abstract}

Thirty-five fruits and seventeen vegetables from Martinique were evaluated for total phenol content (TPC), Vitamin C and carotenoid content. TPC, Vitamin $C$ and carotenoid contents ranged from 11.7 to $978.6 \mathrm{mg} / 100 \mathrm{~g}, 0.1$ to $2853.8 \mathrm{mg} / 100 \mathrm{~g}$ and 9.7 to $9269.7 \mu \mathrm{g} / 100 \mathrm{~g}$ respectively. Fruits and vegetables from Martinique have equivalent or higher TPC, Vitamin $C$ and carotenoid contents than fruits and vegetables from temperate climates. Cashew apple had high values for all three parameters (55.8 mg/100g of Vitamin C, $603 \mathrm{mg} / 100 \mathrm{~g}$ of TPC and $924 \mu \mathrm{g} / 100 \mathrm{~g}$ of carotenoids). Bassignac mango and mamey apple had the highest carotenoid contents, with 3800.3 and 3199.7 $\mu \mathrm{g} / 100 \mathrm{~g}$ respectively. Acerola had the highest Vitamin $\mathrm{C}$ and polyphenol contents with 2853.8 $\mu \mathrm{g} / 100 \mathrm{~g}$ and $727.4 \mathrm{mg} / 100 \mathrm{~g}$ respectively. Pigeon peas had high values for all three parameters ( $569.2 \mathrm{mg} / 100 \mathrm{~g}$ of Vitamin C, $978.6 \mathrm{mg} / 100 \mathrm{~g}$ of TPC and $364.3 \mu \mathrm{g} / 100 \mathrm{~g}$ of carotenoids). Pumpkin and watercress had the highest carotenoid content, with 9269.7 and $4339 \mu \mathrm{g} / 100 \mathrm{~g}$ respectively. TPC, Vitamin C and carotenoid content were significantly impacted by processing techniques. TPC, Vitamin $C$ and carotenoid contents decreased by up to $75.78 \%, 100 \%$ and $70.18 \%$ respectively, depending on the processing technique used.

\section{Keywords}

Martinique Fruits and Vegetables, Total Polyphenols, Vitamin C, Carotenoids, Technology Process, Food Composition, Food Analysis, Nutritional Quality

\footnotetext{
${ }^{*}$ Corresponding author.
}

How to cite this paper: Ellong, E.N., Billard, C., Adenet, S. and Rochefort, K. (2015) Polyphenols, Carotenoids, Vitamin C Content in Tropical Fruits and Vegetables and Impact of Processing Methods. Food and Nutrition Sciences, 6, 299-313. 


\section{Introduction}

Limited information on the nutritional profile of tropical fruits is available but several examples cited below suggest the high nutritional potential of tropical fruits and vegetables. Studies in Africa have shown that high levels of $\beta$-carotene in sweet potato (Ipomoea batatas) could allow diets low in Vitamin A to be rebalanced and thus decrease deficiencies [1]. Similarly, acerola (Malpighia punicifolia) is known to be one of the richest fruits in terms of Vitamin C content (Souci, 2008), whilst $100 \mathrm{~g}$ of fresh guava (Psidium guajava) provides more than $400 \%$ of the recommended daily intake [2]. Many reports are on Asian [3] and African [4] varieties, which are different from those grown in Martinique (F.W.I.). Analytical methods are different and fruits are cultivated under different conditions.

Fruits and vegetables provide an optimum mix of antioxidants, such as Vitamin C, polyphenols and carotenoids [5]-[7]. Fruits are rich in antioxidants that help in lowering incidences of degenerative diseases such as cancer, arthritis, arteriosclerosis, heart disease, inflammation, brain dysfunction and acceleration of the ageing process [8]-[10]. Phenolic compounds represent a major portion of the antioxidants found in many plants [11]. Vitamin $\mathrm{C}$ is also abundant in many fruits and its role in disease prevention may be due to its ability to scavenge free radicals in biological systems [12]. It has been reported that the contribution of phenolic compounds to antioxidant activities is much greater than that of Vitamin C [13].

The impact of processing methods on tropical fruits and vegetables has been little studied. This impact on nutrients from temperate fruits and vegetables is a little known. For broccoli, there was an influence of cooking mode, with a loss of $97 \%$ of flavonoids for microwave-cooked florets, whereas steaming had less significant effects [14]. Blanching broccoli in water led to a 37\% loss of total polyphenols [15]. Similarly, Akissoe et al. [16] reported a $40 \%$ drop in polyphenol content in yams during blanching, regardless of temperature. However, Malkeet [17] did not observe significant loss of polyphenols in boiled, baked or microwaved sweet potato flesh, although for polyphenols in the skin, losses of $42 \%, 55 \%$ and $37 \%$ were noted for cooking in the microwave, oven and water respectively. An increase of $40 \%$ in anthocyanins after 30 minutes of steaming was reported by Yang and Gadi [18], but this increase is not significant (5\%) for longer times.

In this study, selected tropical fruits and vegetables from Martinique were analyzed in order to highlight their nutritional qualities and health benefits and assess the impact of processing, with the ultimate aim being to promote local plant biodiversity. To carry out the study it was necessary to obtain nutritional information for Martinique-grown tropical plants in terms of total polyphenol, Vitamin C and carotenoid contents. In addition, the impact of transformation processes on the nutritional quality of six fruits and vegetables (mamey apple, pumpkin, mandarin, okra, sweet potato and christophine) had to be established.

\section{Materials and Methods}

\subsection{Sampling Procedure}

The varieties selected are representative of varieties cultivated in Martinique. A representative sample was obtained from local markets. Samples were collected from a selection of thirty-five fruits and seventeen vegetables, taking into account geographical and varietal diversity, ratio of production and seasonality. A minimum of 30 pieces for each fruit and vegetable were collected for analysis.

The protocol was applied to the physicochemical characterization of each variety. Preparations were made using pilot equipment. Raw material was treated as it is consumed in Martinique. Fruits were peeled and seeded if necessary, the pulp collected and crushed or pressed and then filtered according to the fruit in question. Vegetables were peeled if necessary and steamed, depending on vegetable type. The samples obtained were frozen and stored at $-18^{\circ} \mathrm{C}$ in sealed plastic bags pending analysis.

\subsection{Physicochemical and Nutritional Characterization of Fruits and Vegetables}

\subsubsection{Total Polyphenols}

Total polyphenols were determined using Folin and Ciocalteu's method described in Georgé et al. [19]. Only the measure of raw extracts was considered. $300 \mathrm{mg}$ to $1 \mathrm{~g}$ of sample was homogenized with $10 \mathrm{~mL}$ of extraction solution (acetone/water, 7/3 vol/vol) for $10 \mathrm{~min}$. The raw extract was obtained after filtration (Whatman). Polyphenols are commonly determined using Folin-Ciocalteu reagent. Absorbance at $760 \mathrm{~nm}$ was determined using a spectrophotometer (JENWAY 7305). Results are expressed in mg of gallic acid equivalent/100g. 


\subsubsection{Total Carotenoids}

Total carotenoids were determined using a colorimetric method. $2 \mathrm{~g}$ of samples were extracted for 30 minutes with $50 \mathrm{~mL}$ of a ternary solvent (hexane/ethanol/acetone 50/25/25). After filtration (Whatman), solvent was washed three times with $25 \mathrm{~mL}$ distilled water. Absorbance at $450 \mathrm{~nm}$ was determined using a spectrophotometer (JENWAY 7305). Results were obtained using the Beer-Lambert law and expressed in $\mu \mathrm{g} / 100 \mathrm{~g}$.

\subsubsection{Vitamin C}

Vitamin C was measured using the K-ASCO 11/05 Megazyme kit. $100 \mu \mathrm{L}$ of samples were incubated for 3 min at $37^{\circ} \mathrm{C}$ with phosphate/citrate buffer and ascorbic acid oxidase. $200 \mu \mathrm{L}$ of tetrazolium salt were added and incubated for $3 \mathrm{~min}$ at $37^{\circ} \mathrm{C}$. $200 \mu \mathrm{L}$ of reactive agent were added and absorbance at $578 \mathrm{~nm}$ was immediately read using a spectrophotometer (JENWAY 7305). Results were obtained using the Beer-Lambert law and expressed in $\mu \mathrm{g} / 100 \mathrm{~g}$. The recommended daily intake determined by the World Health Organization is about $60 \mathrm{mg}$.

For temperate fruits and vegetables, data was based on the worldwide food composition tables.

\subsection{Processing of Fruits and Vegetables}

Raw material processing was performed according to the suitability of the plant (crisps, canned in syrup, freshcut packaged, filtered pasteurized pure juice, flour, frozen or steamed). Treatment of plants was carried out with pilot equipment from the institute's technological hall. All fruits and vegetables were washed, sanitized and peeled before processing.

\subsubsection{Steaming}

Vegetables were cut into pieces of 2 - 4 mm thickness in a BIRO cubing machine and cooked at $110^{\circ} \mathrm{C} / 100 \%$ relative humidity in a FRIMA steam oven until a core temperature of $90^{\circ} \mathrm{C}$ was reached. Pieces were then ground for $3 \mathrm{~min}$ at $1500 \mathrm{rpm}$ with a STEPHAN UM44. Samples were frozen in an ACFRI freezing cell and stored at $-18^{\circ} \mathrm{C}$ before analysis.

\subsubsection{Crisps}

Vegetables were cut into pieces of $2 \mathrm{~mm}$ thickness using a slicing machine. Slices were then immersed in sunflower oil at $120^{\circ} \mathrm{C}$ and -0.85 bar for 400 seconds in a FEMAG vacuum fryer. After frying, the product was drained on paper and centrifuged for 30 seconds to dry and remove excess oils. Samples were ground for 3 min with a STEPHAN UM44 and stored at ambient temperature before analysis.

\subsubsection{Fresh-Cut Packaged}

Vegetables were grated into $2 \mathrm{~mm}$ thick pieces with a ROBOT-COUPE slicing machine. Samples were ground for 3 min with a STEPHAN UM44 and frozen at $-18^{\circ} \mathrm{C}$ before analysis.

\subsubsection{Canning}

$400 \mathrm{~g}$ of fruits were added to $300 \mathrm{~mL}$ of syrup $\left(20^{\circ}\right.$ Brix, $\left.\mathrm{pH} 4.5,75^{\circ} \mathrm{C}\right)$ in $4 / 4$ cans. Cans were sealed with a BERTUZZI sealer and sterilized in a BARRIQUAND autoclave for $20-30 \mathrm{~min}$ at $100^{\circ} \mathrm{C}-115^{\circ} \mathrm{C}$. Vegetables were blanched for $2 \mathrm{~min}$ at $100^{\circ} \mathrm{C}$ in an AURIOL cooking pot. They were then placed in $4 / 4$ cans with blanching water at $70^{\circ} \mathrm{C}$ added with $10 \mathrm{mg} / \mathrm{g}$ salt and $2 \mathrm{mg} / \mathrm{g}$ citric acid. Cans were sealed with a BERTUZZI sealer and sterilized in a BARRIQUAND autoclave for $20-30 \mathrm{~min}$ at $100^{\circ} \mathrm{C}-115^{\circ} \mathrm{C}$. All cans were then opened and products were ground for $3 \mathrm{~min}$ at $1500 \mathrm{rpm}$ in a STEPHAN UM44. Samples were frozen in an ACFRI freezing cell and stored at $-18^{\circ} \mathrm{C}$ before analysis.

\subsubsection{Filtered (Pasteurized) Pure Juice}

Mandarins were peeled and sliced prior to pressing with a BERTUZZI hydraulic press. Juice was filtered and then stored at $-18^{\circ} \mathrm{C}$ before analysis. For pasteurized juice, juice was pasteurized in a BERTUZZI pasteurizer (heat treatment $90^{\circ} \mathrm{C}$ for $4 \mathrm{~min}$ ) and then stored at $-18^{\circ} \mathrm{C}$ pending analysis.

\subsubsection{Flour}

Sweet potatoes were cut into thin $2 \mathrm{~mm}$ thick slices in a slicing machine and dried for $24 \mathrm{hr}$ at $50^{\circ} \mathrm{C}, 40 \%$ rela- 
tive humidity and 70\% ventilation in a FEMAG drier. Dried slices were ground for 3 minutes at $1500 \mathrm{rpm}$ in a STEPHAN UM 44 and then passed through a $300 \mu \mathrm{m}$ sieve with a SAMAP mill. Flour was stored at ambient temperature before analysis.

\subsubsection{Frozen}

Vegetables were cut into 2 - $4 \mathrm{~mm}$ thick slices in a slicing machine, blanched for 2 minutes in a FRIMA steam oven at $90^{\circ} \mathrm{C} 100 \%$ relative humidity, ground for $3 \mathrm{~min}$ at $1500 \mathrm{rpm}$ in a STEPHAN UM 44 and frozen at $-18^{\circ} \mathrm{C}$ in an ACFRI freezing cell and stored at $-18^{\circ} \mathrm{C}$ before analysis.

\subsection{Data Statistical Analysis}

The physical and chemical mean values of triplicate measurements or analysis were statistically analysed. Analysis of Variance (ANOVA) based on Student Test, Principal Component Analysis (PCA) and Duncan's Multiple Range Test (DMRT) were performed using the StatGraphics CENTURION ${ }^{\circledR}$ XV 2005 software and Uniwin PLUS $^{\circledR} 2005$ v6.1.

\section{Results}

\subsection{Food Compositions of Different Fruits and Vegetables}

We wanted to highlight the nutritional profile and potential uses of fruits and vegetables from Martinique. We compared them with commonly consumed temperate plants known for their nutritional potential. Analysis of the results is summarized in Table 1 and Table 2. The TPC ranged from 11.7 to $978.6 \mathrm{mg}$, gallic acid equiv/100g. Vitamin C and carotenoid content ranged from 0.1 to $2853.8 \mathrm{mg} / 100 \mathrm{~g}$ and 9.7 to $9269.7 \mu \mathrm{g} / 100 \mathrm{~g}$ respectively. Table 3 represents TPC, Vitamin C and carotenoid content for temperate fruits and vegetables.

\subsubsection{Food Compositions of Fruits and Vegetables from Martinique}

Figure 1(a) represents vegetables' polyphenol content (mg/100g). The pigeonpea was the richest vegetable studied in terms of total polyphenol content. With $978.6 \mathrm{mg} / 100 \mathrm{~g}$, their TPC was almost four times higher than for artichokes and Brussels sprouts. Okra, yams, malanga, and sweet potatoes were richer in polyphenols than shallots and broccoli. Figure 1(b) shows fruits' polyphenol content in mg/100g. Eight fruits from Martinique were richer than strawberries in terms of polyphenol content. Acerola was richer in polyphenols than acai, with a value of $727 \mathrm{mg} / 100 \mathrm{~g}$ and was the richest fruit from Martinique in terms of polyphenols. Cashew apple and star apple had high values, with 603.0 and $515.0 \mathrm{mg} / 100 \mathrm{~g}$ respectively.

The total carotenoid content of fruits and vegetables was also analyzed. The comparison of tropical (colored) and temperate (black) vegetables' total carotenoid content ( $\mu \mathrm{g} / 100 \mathrm{~g}$ ) is represented in Figure 2(a). Both pumpkin varieties, cress and sweet potatoes were rich in total carotenoids. Pumpkin was richer than carrot and spinach. Sweet potato and cress had higher contents than broccoli. Sweet potato was even 300 times richer than potato, each vegetable registering $2443.3 \mu \mathrm{g} / 100 \mathrm{~g}$ and $6.46 \mu \mathrm{g} / 100 \mathrm{~g}$ respectively. Less colourful vegetables such as cucumber, dasheen, bur cucumber or cassava are poorest in total carotenoids. Figure 2(b) shows the total carotenoid content of fruits from Martinique. Mamey apple and macaque mandarin had total carotenoid contents higher than $2000 \mu \mathrm{g} / 100 \mathrm{~g}$ and were the richest fruits studied. However, mamey apple had a content almost twice that of apricots from temperate regions (Prunus armeniaca). Christophine's total carotenoid content was 28 times higher than globally studied christophine. Tomatoes from Martinique had a carotenoid content equivalent to tomatoes from temperate regions. Finally, malay apple, custard apple and soursop did not contain carotenoids.

Figure 3(a) represents Vitamin C contents (mg/100g) of vegetables from Martinique. Pigeonpea was the richest vegetable for Vitamin C with $569 \mathrm{mg} / 100 \mathrm{~g}$. Its content was three times higher than for peppers and could cover more than $949 \%$ of the recommended daily intake (RDI) of Vitamin C. Massisi ranked fifth with 73 $\mathrm{mg} / 100$ which nevertheless covers $122 \%$ of the RDI. A comparison of Vitamin C content (in mg/100g) of tropical (colored) and temperate (black) fruits, is presented in Figure 3(b). Acerola was the richest for Vitamin C with $2853.8 \mathrm{mg} / 100 \mathrm{~g}$. $100 \mathrm{~g}$ provided more than $4700 \%$ of the RDI. $2 \mathrm{~g}$ of acerola was sufficient to cover $100 \%$ of the RDI of Vitamin C. Its Vitamin C content was more than 1.5 times higher than acerola studied around the world (1700 mg/100g), almost 18 times higher than blackcurrant $(179 \mathrm{mg} / 100 \mathrm{~g})$ and 47 times higher than kiwi (60 mg/100g). Cashew apple and guava were in second and third position with 555.8 and $491.6 \mathrm{mg} / 100 \mathrm{~g}$ respec- 
Table 1. Food composition table for fruits cultivated in Martinique.

\begin{tabular}{|c|c|c|c|c|}
\hline Scientific Names & Fruits & Total Polyphenols (mg/100g) & Total Carotenoids ( $\mu \mathrm{g} / 100 \mathrm{~g})$ & Vitamin C (mg/100g) \\
\hline Anacardium occidentale & Cashew apple & $603 \pm 14$ & $924 \pm 31$ & $555.8 \pm 22.3$ \\
\hline Ananas comosus & Pineapple & $73.3 \pm 5.3$ & $497 \pm 17$ & $38.3 \pm 1.0$ \\
\hline Annona muricata & Soursop & $183.4 \pm 56.7$ & 0 & $16.3 \pm 0.3$ \\
\hline Annona squamosa & Custard apple & $388.3 \pm 7.7$ & 0 & $11.5 \pm 0.1$ \\
\hline Artocarpus heterophyllus & Jackfruit & $101.7 \pm 2.1$ & $131.7 \pm 12.3$ & $13.6 \pm 1.3$ \\
\hline Averrhoa carambola & Star fruit & $366.3 \pm 7.3$ & $112 \pm 19$ & $14.2 \pm 0.3$ \\
\hline Carica papaya & Raw papaya & $43.5 \pm 2.4$ & $113 \pm 11$ & $39.3 \pm 0.3$ \\
\hline Carica papaya & Cooked papaya & $38.6 \pm 4.8$ & $83.3 \pm 3.1$ & $25.7 \pm 0.3$ \\
\hline Chrysophyllum cainito & Star apple & $515 \pm 21$ & $26.3 \pm 1.5$ & $5.6 \pm 1.8$ \\
\hline Citrullus lanatus & Watermelon & $22.8 \pm 4.2$ & $541.7 \pm 39.1$ & $7.9 \pm 0.2$ \\
\hline Citrus aurantifolia & Giant key lime & $213.2 \pm 20.7$ & $63.8 \pm 76.3$ & $23.7 \pm 0.3$ \\
\hline Citrus aurantifolia & Lemon & $111.7 \pm 9.7$ & $446.8 \pm 247.4$ & $23.2 \pm 0.9$ \\
\hline Citrus aurentium & Bitter orange & $350 \pm 74$ & $575.2 \pm 141.7$ & $44.5 \pm 0.8$ \\
\hline Citrus latifolia & Lima citrus & $31.7 \pm 2.7$ & $310.3 \pm 24.6$ & $18.5 \pm 0.3$ \\
\hline Citrus maxima & Shaddock & $112.7 \pm 9.7$ & $909.8 \pm 381.9$ & $44.2 \pm 2.5$ \\
\hline Citrus maxima & Grapefruit & $59.2 \pm 2.3$ & $448.4 \pm 248.1$ & $35.6 \pm 1.2$ \\
\hline Citrus reticulata & Common mandarin & $102.2 \pm 1.4$ & $714.7 \pm 4.1$ & $26.7 \pm 0.6$ \\
\hline Citrus reticulata & Macaque mandarin & $76.2 \pm 0.3$ & $2136.7 \pm 16.2$ & $6.1 \pm 0.0$ \\
\hline Citrus sinensis & Orange & $131.8 \pm 11.9$ & $331.6 \pm 195.8$ & $41.2 \pm 0.7$ \\
\hline Citrus spp, & Sour orange & $83.5 \pm 4.3$ & $525.3 \pm 59.6$ & $29.9 \pm 0.9$ \\
\hline Cucumis melo & Melon & $42.4 \pm 2.4$ & $535.7 \pm 46.1$ & $27.2 \pm 0.3$ \\
\hline Lycopersicum esculentum & Tomato & $42 \pm 1.3$ & $660 \pm 29$ & $15.2 \pm 0.2$ \\
\hline Malpighia punicifolia & Acerola & $727.4 \pm 200.4$ & $422.3 \pm 10.3$ & $2853.8 \pm 10.6$ \\
\hline Mammea americana & Mamey apple & $117.1 \pm 0.3$ & $3199.7 \pm 12.4$ & $2.7 \pm 0.0$ \\
\hline Mangifera indica & Bassignac mango & $95.58 \pm 6.11$ & $2183.00 \pm 642.05$ & $16.0 \pm 11.3$ \\
\hline Mangifera indica & Moussache mango & $57.0 \pm 20.0$ & $449.33 \pm 633.11$ & $30.85 \pm 1.06$ \\
\hline Mangifera indica & Green mango & $86.40 \pm 14.91$ & $276.17 \pm 388.67$ & $28.20 \pm 0.85$ \\
\hline Mangifera indica & Julie mango & $117.50 \pm 7.37$ & $954.00 \pm 52.33$ & $34.50 \pm 13.44$ \\
\hline Passiflora edulis & Passion fruit & $50.4 \pm 1.4$ & $339 \pm 46$ & $54.3 \pm 2.3$ \\
\hline Passiflora laurifolia & Water melon & $44 \pm 9$ & $11 \pm 2$ & $41.4 \pm 0.3$ \\
\hline Psidium guajava & Guava & $422.7 \pm 25.6$ & $604.3 \pm 12.1$ & $491.6 \pm 1.7$ \\
\hline Punica granatum & Pomegranate & $189.6 \pm 35.9$ & $9.7 \pm 1.1$ & $19.8 \pm 1.0$ \\
\hline Spondias cythera Sonnerat & Ripe golden apple & $157 \pm 13$ & $752.7 \pm 14.3$ & $20.1 \pm 0.2$ \\
\hline Spondias cythera Sonnerat & Green golden apple & $158 \pm 5$ & $836.3 \pm 9.3$ & $23.9 \pm 0.4$ \\
\hline Spondias mombin & Hog plum & $250.9 \pm 8.3$ & $821 \pm 22$ & $10.1 \pm 0.1$ \\
\hline Syzygium malaccense & Malay apple & $301 \pm 23$ & 0 & $0.3 \pm 0.1$ \\
\hline
\end{tabular}

Data are expressed per $100 \mathrm{~g}$ of fresh edible material. An asterix indicates fruits treated in juice for analyses. 
Table 2. Food composition table for vegetables cultivated in Martinique.

\begin{tabular}{ccccc}
\hline Scientific Names & Vegetables & Total Polyphenols $(\mathrm{mg} / 100 \mathrm{~g})$ & Total Carotenoids $(\mu \mathrm{g} / 100 \mathrm{~g})$ & Vitamin C $(\mathrm{mg} / 100 \mathrm{~g})$ \\
\hline Abelmoschus esculentus & Okra & $224.9 \pm 25.3$ & $552.3 \pm 35.2$ & $2.9 \pm 0.0$ \\
Artocarpus altilis & Breadfruit & $29.4 \pm 0.2$ & $245.0 \pm 20.6$ & $8.2 \pm 0.1$ \\
Cajanus cajan & Pigeonpea & $978.6 \pm 34.8$ & $364.3 \pm 9.3$ & $569.2 \pm 41.1$ \\
Calathea allouia & Jerusalem artichoke & $29.8 \pm 4.4$ & $136.3 \pm 7.6$ & $9.7 \pm 0.4$ \\
Colocasia esculenta & Dasheen & $87.0 \pm 8.5$ & $51.3 \pm 1.5$ & $4.1 \pm 0.1$ \\
Cucumis anguria & Bur cucumber & $49.4 \pm 7.7$ & $16.7 \pm 3.2$ & $73.2 \pm 1.2$ \\
Cucumis sativus ${ }^{*}$ & Cucumber & $11.7 \pm 4.5$ & $52.0 \pm 1.9$ & $0.3 \pm 0.0$ \\
Cucurbita moschata & Local pumpkin & $27.03 \pm 1.86$ & $9269.7 \pm 25.6$ & $0.1 \pm 0.0$ \\
Cucurbita moschata & Phoenix pumpkin & $31.5 \pm 0.1$ & $7714.7 \pm 20.7$ & $0.1 \pm 0.0$ \\
Dioscorea alata & St. Marteen yam & $214.1 \pm 5.1$ & $86.3 \pm 1.5$ & $22.0 \pm 0.6$ \\
Dioscorea cayenensis-rotunda & Yellow yam & $30.5 \pm 1.4$ & $444.1 \pm 0.1$ & $8.5 \pm 0.1$ \\
Dioscorea trifida & Couscoushe yam & $55.9 \pm 2.4$ & $73.3 \pm 4.2$ & $0.87 \pm 0.05$ \\
Ipomoea batatas & Sweet potato & $30.8 \pm 2.2$ & $2443.3 \pm 25.2$ & $12.5 \pm 0.5$ \\
Manihot esculenta & Sweet cassava & $23.9 \pm 1.4$ & 0 & $21.3 \pm 0.7$ \\
Musa spp. & Plantain & $42.1 \pm 0.1$ & $862.0 \pm 11.8$ & $6.1 \pm 0.1$ \\
Musa spp. & Green banana & $46.6 \pm 1.4$ & $247.7 \pm 2.3$ & $9.2 \pm 0.1$ \\
Nasturtium officinale & Watercress & $90.6 \pm 8.6$ & $4339.0 \pm 15.9$ & $2.7 \pm 0.5$ \\
Sechium edule & White Christophine & $47.2 \pm 8.8$ & $291.0 \pm 7.5$ & $7.4 \pm 0.2$ \\
Sechium edule & Green Christophine & $41.2 \pm 9.4$ & $414.3 \pm 23.4$ & $12.5 \pm 0.3$ \\
Xanthosoma sagittifolium & Malanga & $211.4 \pm 29.0$ & $355.7 \pm 9.6$ & $19.3 \pm 1.2$ \\
\hline
\end{tabular}

Data are expressed per $100 \mathrm{~g}$ of fresh edible material. An asterix indicates raw vegetables for analyses.

Table 3. Food composition table for temperate fruits and vegetables.

\begin{tabular}{|c|c|c|c|c|}
\hline Scientific Names & Fruits and Vegetables & Total Polyphenols (mg/100g) & Vitamin C (mg/100g) & Total Carotenoids ( $\mu \mathrm{g} / 100 \mathrm{~g})$ \\
\hline Euterpe oleracea & Acai & $604.69 \pm 0.00$ & $58.72 \pm 0.00$ & $5.07 \pm 0.00$ \\
\hline Malus domestica & Apple & $179.1 \pm 148.3$ & - & - \\
\hline Prunus armeniaca & Apricot & $133.00 \pm 0.00$ & - & - \\
\hline Cynara scolymus & Artichoke & $321.3 \pm 166.7$ & - & - \\
\hline Rubus fruticosus & Blackberry & $569.43 \pm 226.05$ & $24.57 \pm 9.15$ & $0.27 \pm 0.00$ \\
\hline Ribes nigrum & Blackcurrant & $820.64 \pm 230.06$ & $179.50 \pm 16.46$ & $8 \pm 0$ \\
\hline Vaccinium corymbosum & Blueberries & $525 \pm 0$ & $16.97 \pm 10.09$ & $30 \pm 0$ \\
\hline Brassica oleracea & Broccoli & $98.9 \pm 13.5$ & - & - \\
\hline Brassica oleracea & Brussels Sprout & $220.75 \pm 183.49$ & - & - \\
\hline Vaccinium macrocarpon & Cranberry & $198 \pm 101$ & $11.60 \pm 1.42$ & $200 \pm 0$ \\
\hline Vitis vinifera & Grapes & $153.39 \pm 49.86$ & $6.24 \pm 3.34$ & $30 \pm 0$ \\
\hline Actinidia deliciosa & Kiwi & $315 \pm 0$ & $78.33 \pm 17.15$ & $50 \pm 0$ \\
\hline Morinda citrifolia & Noni & $91.9 \pm 0.0$ & $53.2 \pm 0.0$ & $3.5 \pm 0.0$ \\
\hline Hylocereus undatus & Pitahaya & - & $29 \pm 0$ & - \\
\hline Solanum tuberosum & Potato & $53.86 \pm 34.87$ & $13.50 \pm 4.95$ & $5.2 \pm 0.0$ \\
\hline Rubus idaeus & Raspberry & $148.10 \pm 93.55$ & $26.20 \pm 2.67$ & $30 \pm 0$ \\
\hline Allium сера & Shallot & - & - & - \\
\hline Fragaria virginiana & Strawberry & $289.20 \pm 95.22$ & $64.81 \pm 13.20$ & $20 \pm 0$ \\
\hline
\end{tabular}

Data presented here represent averages from worldwide food composition tables or values found in literature [20]-[35]. 


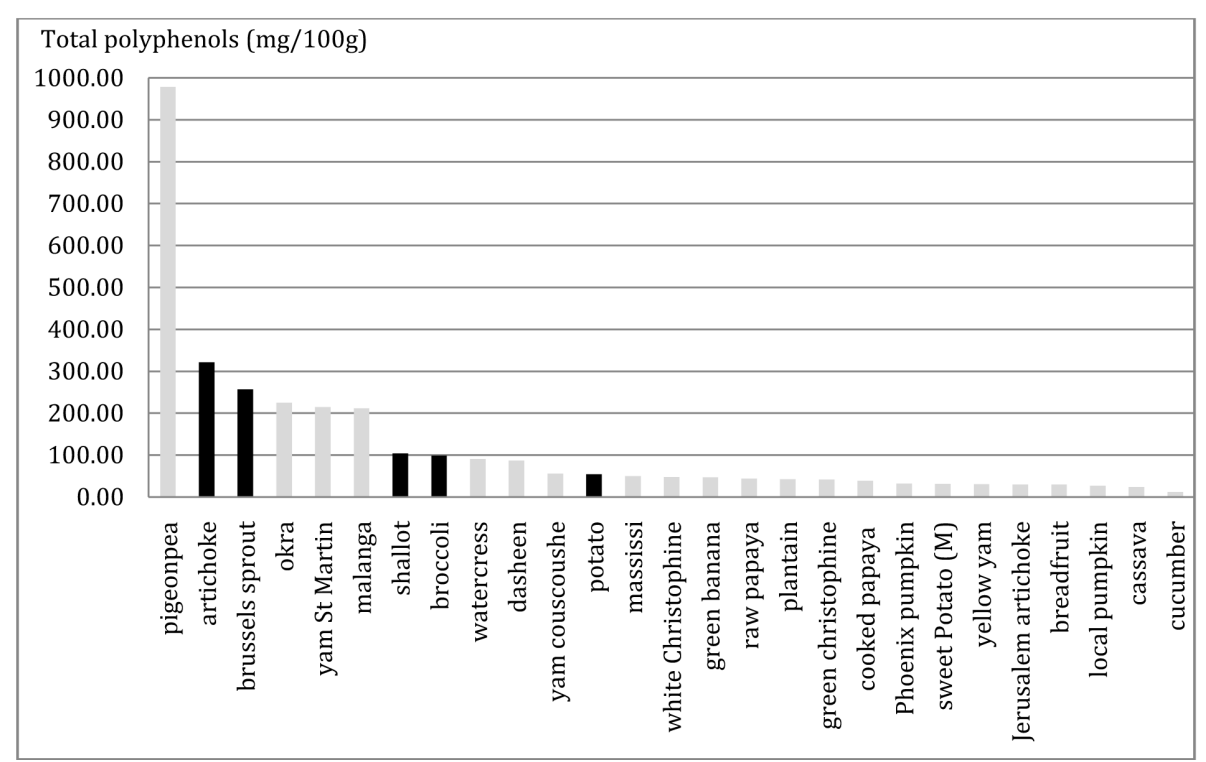

(a)

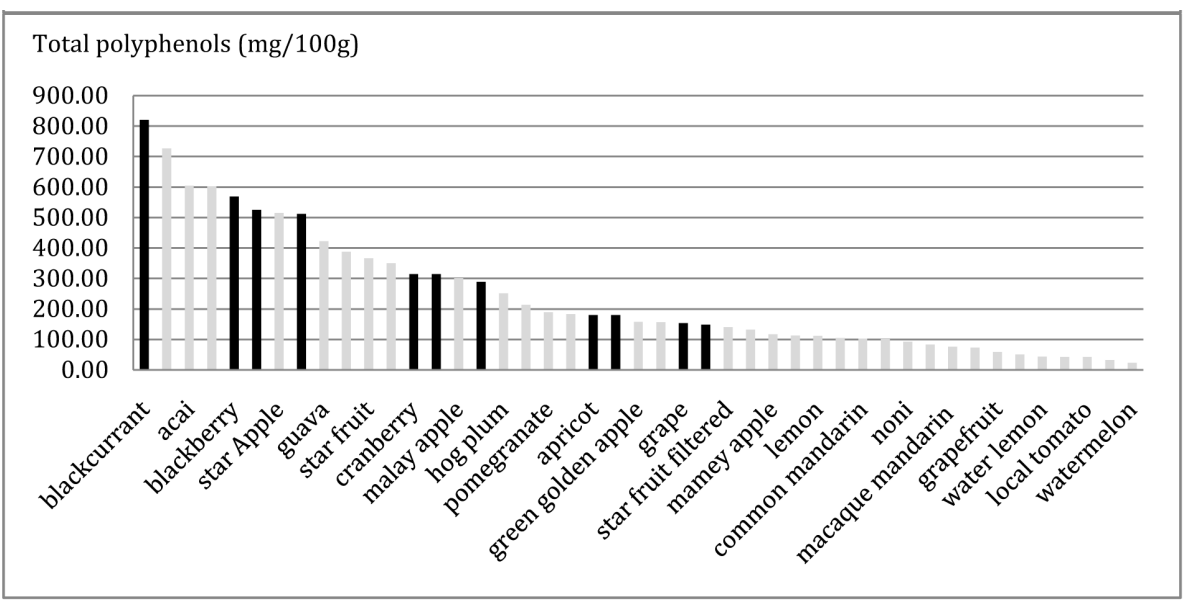

(b)

Figure 1. Comparison of total polyphenol content (mg/100g) of tropical (grey) and temperate (black) vegetables (a) and fruit (b).

tively. Their Vitamin C content was also higher than blackcurrant (more than 3 times higher) and kiwi (more than 9 times higher). Lower down on the scale, pineapple, papaya, passion fruit, and guava covered more than $70 \%$ of RDI, with levels of between 54.3 and $38.3 \mathrm{mg} / 100 \mathrm{~g}$.

\subsubsection{Food Compositions of Temperate Fruits and Vegetables}

Figure 1(a) represents vegetables' polyphenol content (mg/100g). Temperate vegetables have been added for comparison (artichoke, brussels sprout, shallot and broccoli, shown in black in the figures). Pigeon peas were nine times richer in polyphenols than shallots, with $104 \mathrm{mg} / 100 \mathrm{~g}$. Figure 1(b) shows fruits' polyphenol content in $\mathrm{mg} / 100 \mathrm{~g}$. Temperate fruits with a high nutritional profile have been added for comparison (black bars in the charts). Apples, grapes and raspberries, commonly found and widely consumed in temperate climates, have lower polyphenol values-less than $180 \mathrm{mg} / 100 \mathrm{~g}$.

Total carotenoid content $(\mu \mathrm{g} / 100 \mathrm{~g})$ is represented in Figure 2(a). Temperate fruits and vegetables were less rich in total carotenoids than fruits and vegetables from Martinique. Figure 2(b) shows the total carotenoid content of commonly consumed temperate fruits, and "super fruits" known for their high levels of carotenoids. Acai had a content 1.6 times higher than mamey apple. 


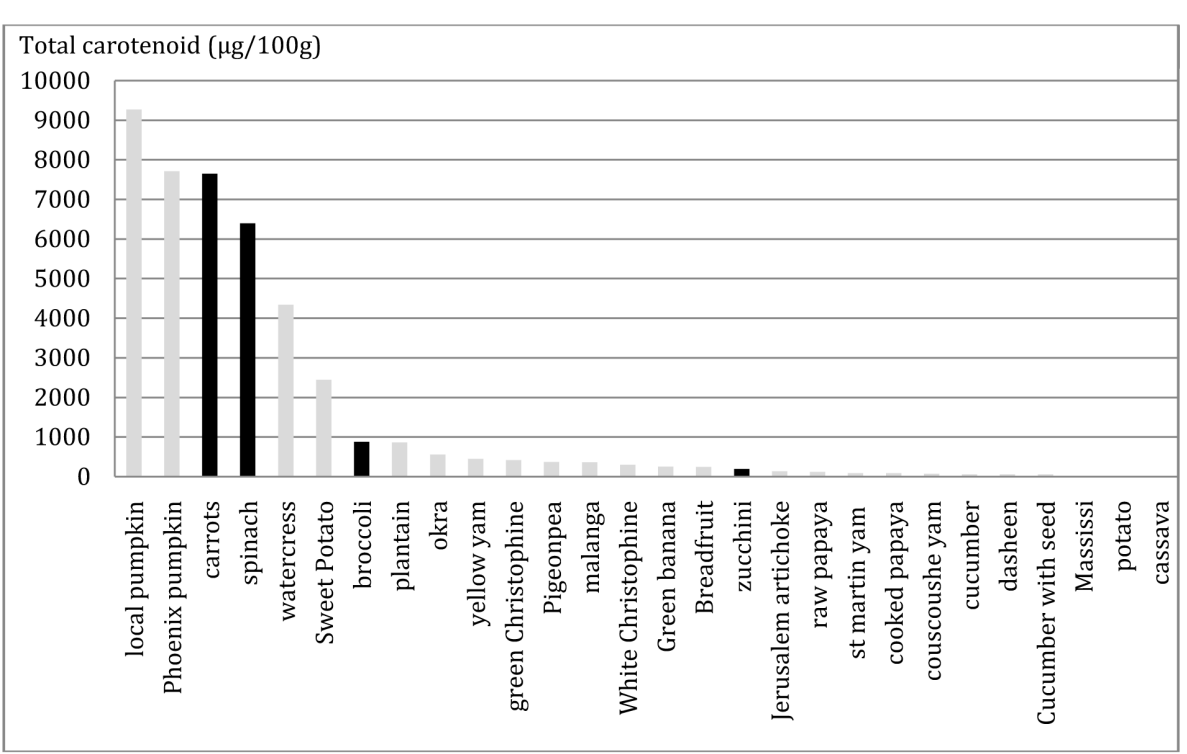

(a)

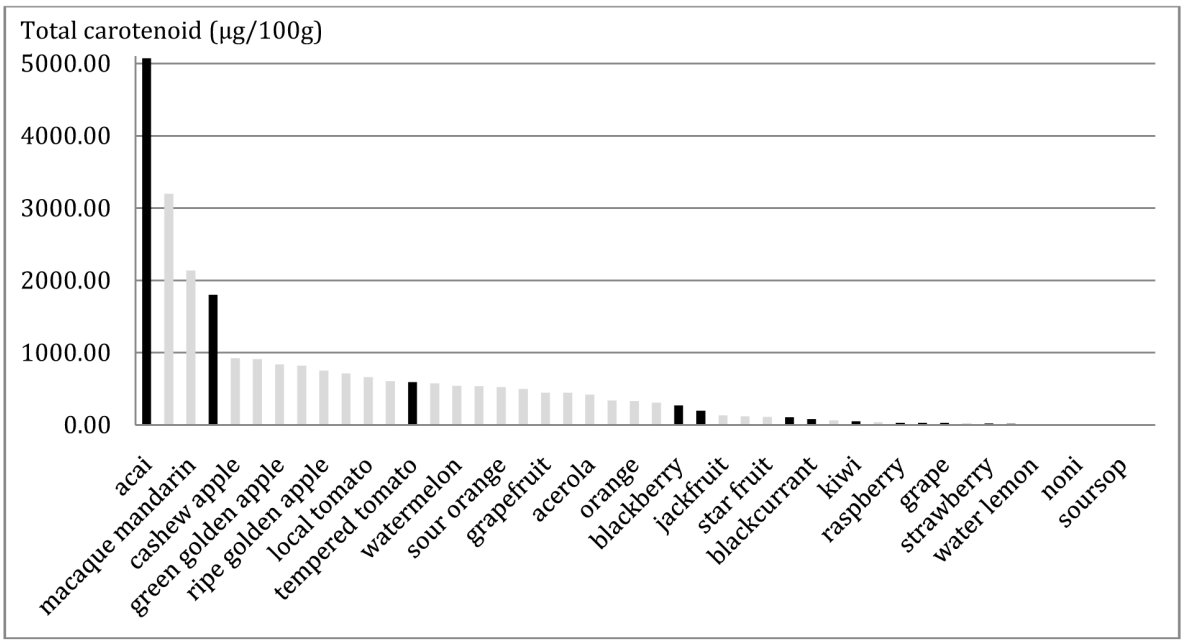

(b)

Figure 2. Comparison of total carotenoid content ( $\mu \mathrm{g} / 100 \mathrm{~g})$ in tropical (colored) and temperate (black) vegetables (a) and fruit (b).

Figure 3(a) represents Vitamin C contents (mg/100g) of some vegetables known for their high Vitamin C contents, and other commonly consumed vegetables (peppers, Brussels sprouts, broccoli, zucchini). Martinique fruits and vegetables are richer in Vitamin $\mathrm{C}$ than temperate fruits and vegetables.

\subsection{Impact of Processing on Micronutrients}

Data from the processing of some of the fruits and vegetables from Martinique was established. Two fruits and four vegetables were specifically studied here: mamey, mandarin, pumpkin, okra, sweet potato and christophine. Results are summarized in Table 4. This allowed a comparison of the nutritional composition of the raw material and the processed material, to highlight the impact of processesing on micronutrients. Data is for $100 \mathrm{~g}$ of dry matter. For almost all fruits and vegetables studied, raw materials had the highest total polyphenols, carotenoids and Vitamin C content. Mamey apple was rich in polyphenols and total carotenoids. Raw materials had 804.17 mg of polyphenols and $21.97 \mathrm{mg}$ of total carotenoids. Mandarin was also rich in polyphenols, total carotenoid and Vitamin C, with $1022.11 \mathrm{mg}, 7.15 \mathrm{mg}$ and $266.79 \mathrm{mg}$ respectively. Pumpkin was rich in total carotenoids, with $97.79 \mathrm{mg}$. Christophine was rich in polyphenols and a good source of Vitamin C, with $278.23 \mathrm{mg}$ and 77.43 


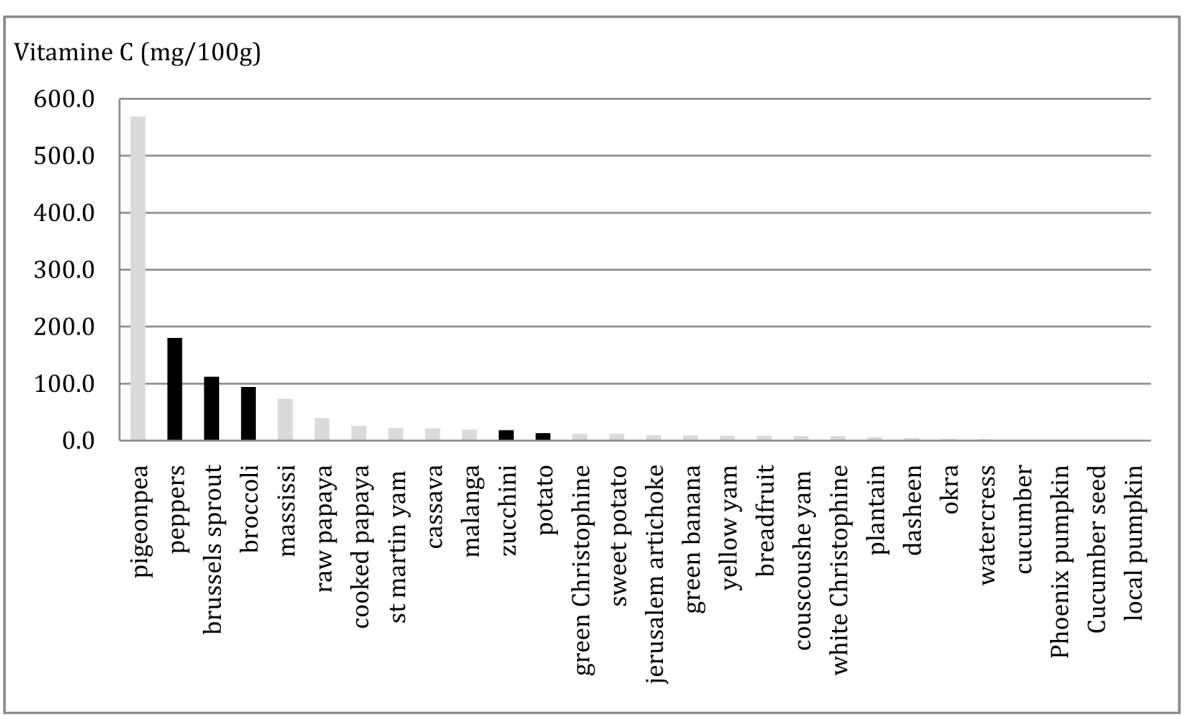

(a)

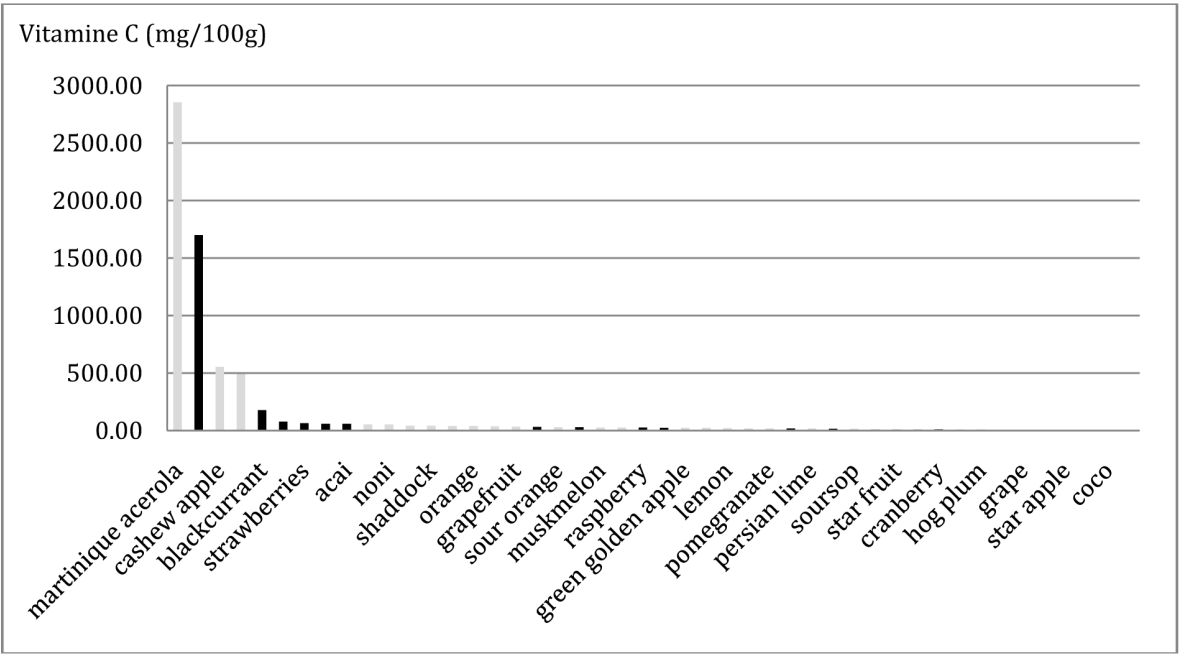

(b)

Figure 3. Comparison of Vitamin C content (mg/100g) in tropical (colored) and temperate (black) vegetables (a) and fruit (b).

mg respectively. Sweet potatoes were rich in total polyphenols (373.84 mg) and carotenoids (3.84 mg), and were a source of Vitamin C (16.00 mg). Sweet potato flour was very rich in carotenoids (3.43 mg) and total polyphenols $(587.77 \mathrm{mg}$ ). Okra was rich in total polyphenols, with $1800.90 \mathrm{mg}$. Its total polyphenol content was 19 times richer than broccoli.

\subsubsection{Impact on Total Polyphenols}

The total polyphenol content was statistically the highest (5\%) in the raw material for all fruits and vegetables, except for pumpkin, where it was higher in the fresh-cut packaged product. Heat treatments had a statistically significant effect (5\%) on total polyphenol content. The processes of pasteurization, sterilization (canning) and vacuum frying (chips) were in the lowest statistical groups. Steaming had the least impact on total polyphenols. Cooking methods had a statistically significant effect (5\%) on total polyphenol content. The more fruits and vegetables were heated, the more their polyphenol content decreased.

For products made from mamey apples, a significant loss of total polyphenols between the raw material and processed products was observed. The loss was statistically higher in chips. There was a $42 \%$ loss of total polyphenols in canned products and $76 \%$ in chips compared to the raw material. During the preparation of peach sy- 
Table 4. Impact of processing on micronutrients for fruits and vegetables from Martinique. Letters (a, b, c) indicate a significant difference at $5 \%$ (Fischer test). All results are expressed per $100 \mathrm{~g}$ of dry matter.

\begin{tabular}{|c|c|c|c|c|}
\hline Plant & Product/Process & Total Polyphenols (mg) & Total Carotenoids (mg) & Vitamin C (mg) \\
\hline \multirow{3}{*}{ Mamey } & crushed raw (raw material) & $804.17 \pm 7.27 \mathrm{a}$ & $21.97 \pm 0.31$ a & $18.60 \pm 0.21 \mathrm{a}$ \\
\hline & canned & $463.88 \pm 2.60 \mathrm{~b}$ & $9.95 \pm 0.14 b$ & $0.00 \pm 0.00 \mathrm{~b}$ \\
\hline & crisps & $194.77 \pm 2.15 \mathrm{c}$ & $6.55 \pm 0.16 \mathrm{c}$ & $0.20 \pm 0.00 \mathrm{~b}$ \\
\hline \multirow[t]{2}{*}{$\mathbf{p}$} & & 0.0000 & 0.0000 & 0.0000 \\
\hline & steamed crushed (raw material) & $333.23 \pm 14.26$ c & $97.79 \pm 17.23 \mathrm{a}$ & \\
\hline \multirow{3}{*}{ Pumpkin } & fresh-cut packaged & $467.89 \pm 45.95 \mathrm{a}$ & $79.44 \pm 12.24 \mathrm{~b}$ & \\
\hline & frozen & $406.25 \pm 18.17 \mathrm{~b}$ & $64.29 \pm 3.93 \mathrm{c}$ & - \\
\hline & crisps & $380.71 \pm 72.49$ bc & $29.61 \pm 1.06 \mathrm{~d}$ & \\
\hline \multirow[t]{2}{*}{$\mathbf{p}$} & & 0.0004 & 0.0000 & \\
\hline & pure filtered juice (raw material) & $1022.11 \pm 15.20$ a & $7.15 \pm 0.16 \mathrm{a}$ & $266.79 \pm 10.29 a$ \\
\hline \multirow[t]{2}{*}{ Mandarin } & pure filtered pasteurized juice & $851.33 \pm 57.24 b$ & $7.55 \pm 0.46 \mathrm{a}$ & $248.17 \pm 19.47 \mathrm{a}$ \\
\hline & canned & $469.88 \pm 76.13 \mathrm{c}$ & $5.48 \pm 0.82 b$ & $1.25 \pm 0.17 \mathrm{~b}$ \\
\hline \multirow[t]{2}{*}{$\mathbf{p}$} & & 0.0001 & 0.0081 & 0.0000 \\
\hline & steamed crushed (raw material) & $1800.90 \pm 209.16 \mathrm{a}$ & $4.43 \pm 0.33 \mathrm{~b}$ & \\
\hline \multirow[t]{2}{*}{ Okra } & frozen & $1341.23 \pm 18.74 \mathrm{~b}$ & $10.36 \pm 0.96 \mathrm{a}$ & \\
\hline & canned & $1049.45 \pm 63.60 \mathrm{c}$ & $1.55 \pm 0.13 \mathrm{c}$ & \\
\hline \multirow[t]{2}{*}{$\mathbf{p}$} & & 0.0010 & 0.0000 & \\
\hline & steamed crushed (raw material) & $373.84 \pm 7.36 \mathrm{~b}$ & $3.84 \pm 0.14 b$ & $16.00 \pm 0.07 \mathrm{a}$ \\
\hline \multirow[t]{2}{*}{ Sweet potato } & frozen & $340.27 \pm 8.10 \mathrm{~b}$ & $6.22 \pm 0.08 \mathrm{a}$ & $10.83 \pm 0.12 b$ \\
\hline & flour & $587.77 \pm 29.25 \mathrm{a}$ & $3.43 \pm 0.06 \mathrm{c}$ & $0.00 \pm 0.00 \mathrm{c}$ \\
\hline \multirow[t]{2}{*}{$\mathbf{p}$} & & 0.0000 & 0.0000 & 0.0000 \\
\hline & steamed crushed (raw material) & $278.23 \pm 28.52 \mathrm{a}$ & & $77.43 \pm 3.86 \mathrm{a}$ \\
\hline \multirow{2}{*}{$\begin{array}{l}\text { Christophine } \\
\text { (white) }\end{array}$} & frozen & $285.11 \pm 55.61 \mathrm{a}$ & & $72.81 \pm 5.66 \mathrm{a}$ \\
\hline & canned & $249.73 \pm 17.71 \mathrm{a}$ & & $3.42 \pm 0.85 b$ \\
\hline $\mathbf{p}$ & & 0.5565 & & 0.0000 \\
\hline
\end{tabular}

rup, Asami et al. [36] reported losses of 21\% of total polyphenols. Fresh-cut packaged pumpkin had a significantly higher polyphenol content. Statistically, pumpkin chips contained the fewest polyphenols compared to other products made from the vegetable. Price et al. [37] showed that cooking onions by boiling or frying caused a loss of $25 \%$ of flavonol glycosides.

For mandarins, there was a difference of 53\% between the polyphenol content of the pure fresh juice and pure pasteurized juice. For canned fruit, the gap between fresh and processed widens to 86\%. Jiratanan and Liu [38] showed that after treatment at $121^{\circ} \mathrm{C}$, beetroot polyphenol content changed only slightly while French beans had a marked loss (-30\%).

In the case of christophine and okra, the total polyphenol content was significantly (5\%) the highest in raw and frozen material, whilst canned products were in the lowest statistical group.

Statistically, sweet potato flour had the lowest polyphenol content. It was almost 3.5 times lower than for steamed sweet potatoes. After drying for 24 hours at $60^{\circ} \mathrm{C}$, Yang and Gadi [18] found an increase of $50 \%$ in phenolic anthocyanins but not for total anthocyanins. Conversely, Asami et al. [39] showed significantly decreased polyphenol content $(-1 / 3)$ in dried strawberries. 


\subsubsection{Impact on Total Carotenoids}

There was a significant loss of carotenoids following food processing of mamey apples. The highest loss was for chips. Nevertheless, chips still had a carotenoid content 100 times greater than that of potato chips [2]. For dry matter, there was a loss of $55 \%$ of total carotenoids in canned products and $70 \%$ in chips compared to raw material. Cano and de Ancos [40] reported a degradation of total carotenoids in canned mangoes. Only $\beta$-carotene was maintained at $90 \%$. Heat treatment of canned papaya slices caused a loss of $39 \%$ of carotenoids [41].

For pumpkin, primary raw material (cooked/crushed) had the statistically higher carotenoid content (compared with dry matter). Chips had a significantly lower carotenoid content. Frozen pumpkin cubes were in third position behind fresh-cut packaged.

Total carotenoid content of mandarin products was significantly higher in pure juice. Canned mandarin had the lowest content. In a study on total carotenoid composition of cashew apple juice, both fresh and pasteurized, Cecchi and Rodriguez-Amaya [42] reported a loss of carotenoids during the manufacturing process, which including sieving and heating, while carotenoid degradation increased with higher temperatures.

Carotenoid content was statistically higher in frozen okra and in raw material (cooked and crushed). Canned okra was in the lowest statistical group. There was a difference of $+57 \%$ in frozen compared to raw material and a difference of $+85 \%$ between frozen and canned.

Total carotenoid content of frozen sweet potatoes was statistically the highest. It was more than 1.5 times higher than the crushed cooked sweet potato (raw material). Carotenoid content measured by Reddy and Sistrunk [43] in oven-cooked, steamed and canned sweet potatoes showed no significant difference. Water and microwave cooking nevertheless resulted in the lowest contents. Statistically, sweet potato flour had the least total carotenoids. This low content is due to oxidation of these compounds during the manufacturing process. Bechoff et al. [44] evaluated the loss of carotenoids at between 13\% and 33\% for different drying methods.

\subsubsection{Impact on Vitamin C}

A significant loss (5\%) of the total Vitamin C between raw material and processed products in mamey apples was observed. There was no significant difference between canned and chips.

There was no significant difference between pure filtered mandarin juice and the pasteurized juice. There was lower loss of Vitamin C in orange juices following conventional treatment (9\%), but much less when lower temperatures were applied [45]. Vitamin C content was significantly lower in canned mandarin. The loss of Vitamin C during sterilization is very significant. Vitamin C content of canned mandarin slices was the lowest and the difference compared to filtered fresh juice was more than $99 \%$.

Vitamin C content of steamed sweet potatoes (raw material) was statistically the highest, followed by blanched frozen sweet potatoes. Amiot-Carlin et al. [45] reported that Vitamin C content generally decreased significantly following technological operations such as blanching. For peppers, a 12\% loss of Vitamin C was observed after blanching [46].

Sweet potato flour was in the lowest statistical group with a total loss of Vitamin C. Vitamin C was sensitive to air drying. For peppers, the result of drying was an 88\% loss of Vitamin C [46].

There was no significant difference (5\%) in the Vitamin C content of steamed and blanched frozen christophine (raw material). Vitamin C content was significantly lowest in canned. Blanched frozen christophines were 1.5 times richer in Vitamin C than global values for zucchini and frozen green beans.

\section{Discussion}

This study highlights the nutritional profile and potential uses of fruits and vegetables from Martinique. Overall, fruit and vegetable from Martinique were richer than temperate fruits and vegetables in polyphenols, Vitamin C and total carotenoids. The antioxidant potential of tropical fruits and vegetables is little studied to date, and this first study demonstrates the richness of these plants, often not consumed. Lim et al. [47] found that guava, papaya and star fruit have higher primary antioxidant potential than orange (as measured by scavenging DPPH and iron (III) reducing assays). Luximon-Ramma et al. [4] demonstrated in common Mauritian exotic fruits, that there were strong correlations between antioxidant activity and total polyphenols, while very poor correlations were observed between Vitamin C content and antioxidant activity. The highest antioxidant capacities were observed in starfruit and guava. These Mauritian fruits were also characterized by high levels of total polyphenols. Mauritian exotic fruits are thus a significant source of phenolic antioxidants, which may have potential benefi- 
cial effects on health, such as fruits from Martinique. Finally, Ruffino et al. [48] showed promising perspectives for the exploitation of tropical fruit species with considerable levels of nutrients and antioxidant capacity, such as the considerable antioxidant capacity found for acerola, comparable to the fruit of Martinique.

In general, processing treatments had an effect on various nutrient contents in plants from Martinique. Heat treatment and cooking had a statistically significant effect. Boiling caused the diffusion of total polyphenols, while steaming had less impact. There was a statistically significant effect of vacuum frying on total carotenoid content. This loss was due to the distribution of carotenoids, which are soluble compounds, in the cooking oil. Total carotenoids were sensitive to oxidation and, to a lesser extent, sterilization. There was a statistically significant effect (5\%) on Vitamin C content from sterilization, vacuum frying, drying and steaming. This effect was even more pronounced the higher the temperature and the longer the processing time. There is higher nutritional value in consuming a portion of fresh mamey because of its Vitamin C and antioxidant content. Although chips concentrated nutrients (carotenoids and total polyphenols) compared to raw material, their consumption provided fat and carbohydrates. A portion of mamey chips provides twice the level of carotenoids, 1.5 times the total polyphenols and twice as much fibre compared to the fresh fruit, but five times the carbohydrates and more than 100 times the fat. Pumpkin is of high nutritional value with a high carotenoid content. It is better to consume a steamed pumpkin portion for its carotenoid content whilst fresh-cut packaged is of value for the total polyphenol content. As for fresh mamey, we found that processing into chips concentrated nutrients (total polyphenols and carotenoids) but added fat. Pasteurization had little impact on nutritional and functional quality of mandarins. However, filtration of juice leads to the retention of several nutrients. Finally, sterilization resulted in a significant loss of vitamins. From a nutritional standpoint, it is better to consume pure mandarin juice for its Vitamin C and polyphenol contents. Steamed or frozen Okra (subsequently steamed) were very rich in total carotenoids and total polyphenols. Consumption in these forms offers a higher nutritional profile than consumption of the canned vegetable. Steamed sweet potato from Martinique was rich in carotenoids and polyphenols and a source of Vitamin C. Consumption of steamed or frozen (subsequently blanched) offers a higher nutritional profile than its consumption as sweet potato flour. Similarly, consumption of christophine after steaming offers more nutrients than its frozen or canned form. It was rich in antioxidants and a source of Vitamin C.

Cooking methods statistically decreased total polyphenol contents. Polyphenols are hydrosoluble and losses observed during blanching/freezing and sterilization processes are due to diffusion of these nutrients in blanching water and in cooking juices. Anthocyanin content decreased as blanching time increased [49]. Boiling in water caused flavonol losses of $20 \%$ and $40 \%$ respectively for onions and asparagus [50]. Price et al. [37] showed that canning did not cause chemical degradation of glycosides and flavonol, but losses occured through diffusion into cooking solutions, which varied depending on the compound. Vacuum frying had a statistically significant effect on carotenoid content. This loss was due to the diffusion of carotenoids, which are soluble compounds, in the frying oil. Total carotenoids might be susceptible to oxidation and sterilization, but to a lesser extent. Sahlin et al. [51] reported that frying tomato slices led to a higher loss of lycopene than boiling or steaming (decrease of 50\% compared to fresh slices). Similarly, frying carrots showed a higher decrease in total carotenoid content than boiling or steaming [52]. The loss of carotenoids in the fresh-cut packaged products may be due to their oxidation during the manufacturing process. Degradation of carotenoids was due to light (photo-oxidation) or heat [53]. We observed a decrease in Vitamin C content during processing. In a study on the effects of different cooking methods on vegetables, Miglio et al. [52] showed a total loss of ascorbic acid when carrots were fried. Rickman et al. [54] reported systematic losses of ascorbic acid during heat treatment—up to $90 \%$ for canned carrots.

\section{Conclusions}

Tropical plants studied here had high nutritional and functional potential, especially in terms of antioxidant (polyphenols, carotenoids) and vitamin (nutrition) levels. The results showed that these values are equivalent to or even much higher than the levels found in commonly-consumed temperate plants known for their nutritional qualities. Fruits and vegetables from Martinique had a significant advantage in terms of their antioxidant capacity.

In conclusion, in order to get the most nutritional and functional value from tropical fruits and vegetables, it is recommended to consume them in fresh form for fruits, whilst vegetables should be eaten raw or cooked lightly using a method such as steaming. Boiling causes the diffusion of minerals and total polyphenols. Vacuum frying 
promotes a loss of total carotenoids and adds much more fat to the end product. Finally, cooking for longer times and at high temperatures, which is the case for sterilization (canning), causes a sharp decrease in vitamin content. Overall, this study shows that fruits and vegetables grown in Martinique provide numerous health benefits for humans.

\section{Acknowledgements}

We would like to thank the Regional Council of Martinique (F.W.I.) and the FEDER for its financial support. Special thanks also go to producers who provided fruits and vegetables for the study. Ms. Annie Batten is also greatly thanks for her help in English proof reading.

\section{References}

[1] Hagenimana, V., Carey, E.E., Gichuki, S.T., Oyunga, M.A. and Imungi, J.K. (1998) Carotenoid Contents in Fresh, Dried and Processed Sweetpotato Products. Ecology of Food and Nutrition, 37, 455-473. http://dx.doi.org/10.1080/03670244.1998.9991560

[2] Souci, S.W., Fachmann, W. and Kraut, H. (2000) Food Composition and Nutrition Tables. Die zusammensetzung der lebensmittel, nährwert-tabellen. La composition des aliments, tableux des valeurs nutritives. Auflage, bearbeitet von $\mathrm{H}$. SCHERZ und F. SENSER) Medpharm Scientific Publishers, Stuttgart.

[3] Leong, L.P. and Shui, G. (2002) An Investigation of Antioxidant Capacity of Fruits in Singapore Markets. Food Chemistry, 76, 69-75. http://dx.doi.org/10.1016/S0308-8146(01)00251-5

[4] Luximon-Ramma, A., Bahorun, T. and Crozier, A. (2003) Antioxidant Actions and Phenolic and Vitamin C Contents of Common Mauritian Exotic Fruits. Journal of the Science of Food and Agriculture, 83, 496-502. http://dx.doi.org/10.1002/jsfa.1365

[5] Ness, A.R. and Powles, J.W. (1997) Fruit and Vegetables, and Cardiovascular Disease: A Review. International Journal of Epidemiology, 26, 1-13. http://dx.doi.org/10.1093/ije/26.1.1

[6] Esterbauer, H., Dieber-Rotheneder, M., Striegl, G. and Waeg, G. (1991) Role of Vitamin E in Preventing the Oxidation of Low-Density Lipoprotein. The American Journal of Clinical Nutrition, 53, 314-321.

[7] Eastwood, M.A. (1999) Interaction of Dietary Antioxidants in Vivo: How Fruit and Vegetables Prevent Disease? QJM, 92, 527-530. http://dx.doi.org/10.1093/qjmed/92.9.527

[8] Feskanich, D., Ziegler, R.G., Michaud, D.S., Giovannucci, E.L., Speizer, F.E., Willett, W.C. and Colditz, G.A. (2000) Prospective Study of Fruit and Vegetable Consumption and Risk of Lung Cancer among Men and Women. Journal of the National Cancer Institute, 92, 1812-1823. http://dx.doi.org/10.1093/jnci/92.22.1812

[9] Gordon, M.H. (1996) Dietary Antioxidants in Disease Prevention. Natural Product Reports, 13, 265-273. http://dx.doi.org/10.1039/np9961300265

[10] Halliwell, B. (1996) Free Radicals, Proteins and DNA: Oxidative Damage versus Redox Regulation. Biochemical Society Transactions, 24, 1023-1027.

[11] Duthie, G. and Crozier, A. (2000) Plant-Derived Phenolic Antioxidants. Current Opinion in Lipidology, 11, 43-47. http://dx.doi.org/10.1097/00041433-200002000-00007

[12] Block, G. (1991) Vitamin C and Cancer Prevention: The Epidemiologic Evidence. The American Journal of Clinical Nutrition, 53, 270-282.

[13] Wang, H., Cao, G. and Prior, R.L. (1996) Total Antioxidant Capacity of Fruits. Journal of Agricultural and Food Chemistry, 44, 701-705. http://dx.doi.org/10.1021/jf950579y

[14] Vallejo, F., Tomás-Barberán, F. and García-Viguera, C. (2003) Health-Promoting Compounds in Broccoli as Influenced by Refrigerated Transport and Retail Sale Period. Journal of Agricultural and Food Chemistry, 51, 3029-3034. http://dx.doi.org/10.1021/jf021065j

[15] Puupponen-Pimiä, R., Häkkinen, S.T., Aarni, M., Suortti, T., Lampi, A.M., Eurola, M. and Oksman-Caldentey, K.M. (2003) Blanching and Long-Term Freezing Affect Various Bioactive Compounds of Vegetables in Different Ways. Journal of the Science of Food and Agriculture, 83, 1389-1402. http://dx.doi.org/10.1002/jsfa.1589

[16] Akissoe, N., Mestres, C., Hounhouigan, J. and Nago, M. (2005) Biochemical Origin of Browning during the Processing of Fresh Yam (Dioscorea spp.) into Dried Product. Journal of Agricultural and Food Chemistry, 53, 2552-2557. http://dx.doi.org/10.1021/jf040265n

[17] Malkeet, S.P. (2006) Phenolic Composition and Antioxidant Activity of Sweet Potatoes (Ipomoea batatas (L.) Lam). Dissertation, Graduate Faculty of the Louisiana State University, Baton Rouge, 90.

[18] Yang, J. and Gadi, R.L. (2008) Effects of Steaming and Dehydration on Anthocyanins, Antioxidant Activity, Total 
Phenols and Color Characteristics of Purple-Fleshed Sweet Potatoes (Ipomoea batatas). American Journal of Food Technology, 3, 224-234. http://dx.doi.org/10.3923/ajft.2008.224.234

[19] Georgé, S., Brat, P., Alter, P. and Amiot, M.J. (2005) Rapid Determination of Polyphenols and Vitamin C in PlantDerived Products. Journal of Agricultural and Food Chemistry, 53, 1370-1373. http://dx.doi.org/10.1021/jf048396b

[20] Closa, S.J. and De Landeta, M.C. (2002) Tabla de composición de alimenta. Universidad National de Luján. http://www.unlu.edu.ar/ argenfoods/Tablas/Tabla.htm

[21] National Food Institute, Technical University Danemark (2008) Danish Food Composition Databank ed. 7-01. http://www.foodcomp.dk

[22] Favier, J.C., Ireland-Ripert, J., Toque, C. and Feinberg, M. (1995) Répertoire général des aliments: Table de Composition $=$ Composition Tables.

[23] National Institute for Health and Welfare, Nutrition Unit (2008) Fineli Food Composition Database Release 9. http://www.fineli.fi/index.php?lang=en

[24] NUTTAB 2006 Australian Food Composition Tables (2006) Food Standard. http://www.foodstandards.gov.au/science/monitoringnutrients/nutrientables/Pages/default.aspx

[25] Dignan, C., Burlingame, B., Kumar, S. and Aalbersberg, W. (2004) Pacific Islands Food Composition Table. 2nd Edition, FAO. http://www.fao.org/docrep/007/y5432e/y5432e00.htm

[26] Phenol Explorer (2014) Data Base on Polyphenol Content in Foods. http://www.phenol-explorer.eu/

[27] Souci, S.W., Fachmann, W. and Kraut, H. (2000) Food Composition and Nutrition Tables. Die zusammensetzung der lebensmittel, nährwert-tabellen. La composition des aliments, tableux des valeurs nutritives. Auflage, bearbeitet von $H$. SCHERZ und F. SENSER. Medpharm Scientific Publishers, Stuttgart.

[28] NMRC South Africa (2008) South Africa Food Composition Table. http://databases.mrc.ac.za/FoodComp/

[29] Tabela Brasileira de composição de Alimentos USP (2008) Departamento de Alimentos e Nutrição Experimental FCF/ USP. http://www.fcf.usp.br/tabela/

[30] Nutrient Data Laboratory (2008) USDA National Nutrient Database for Standard Reference. http://www.nal.usda.gov/fnic/foodcomp/search/

[31] Beltran-Orozco, M.C. (2009) Ascorbic Acid, Phenol Content and Antioxidant Capacity of Red, Cherry, Yellow and White Types of Pitaya Cactus Fruit (Stenocereus stellatus Riccobono). Agrociencia, 43, 153-161.

[32] Bramorski, A., Cherem, A.D.R., Marmentini, C.P., Torresani, J., Mezadri, T. and Costa, A.D.A.S. (2010) Total Polyphenol Content and Antioxidant Activity of Commercial Noni (Morinda citrifolia L.) Juice and Its Components. Brazilian Journal of Pharmaceutical Sciences, 46, 651-656. http://dx.doi.org/10.1590/S1984-82502010000400006

[33] Neida, S. and Elba, S. (2007) Caracterización del acai o manaca (Euterpe Olerácea Mart.): Un fruto del Amazonas. Archivos Latino Americanos, 57, 94-99.

[34] Price, K.R., Casuscelli, F., Colquhoun, I.J. and Rhodes, M.J. (1998) Composition and Content of Flavonol Glycosides in Broccoli Florets (Brassica olearacea) and Their Fate during Cooking. Journal of the Science of Food and Agriculture, 77, 468-472. http://dx.doi.org/10.1002/(SICI)1097-0010(199808)77:4<468::AID-JSFA66>3.0.CO;2-B

[35] Nelson, S.C. and Elevitch, C.R. (2006) Noni: The Complete Guide for Consumers and Growers. Permanent Agriculture Resources, Holualoa.

[36] Asami, D.K., Hong, Y.J., Barrett, D.M. and Mitchell, A.E. (2003) Comparison of the Total Phenolic and Ascorbic Acid Content of Freeze-Dried and Air-Dried Marionberry, Strawberry, and Corn Grown Using Conventional, Organic, and Sustainable Agricultural Practices. Journal of Agricultural and Food Chemistry, 51, 1237-1241. http://dx.doi.org/10.1021/jf020635c

[37] Price, K.R., Casuscelli, F., Colquhoun, I.J. and Rhodes, M.J. (1998) Composition and Content of Flavonol Glycosides in Broccoli Florets (Brassica olearacea) and Their Fate during Cooking. Journal of the Science of Food and Agriculture, 77, 468-472. http://dx.doi.org/10.1002/(SICI)1097-0010(199808)77:4<468::AID-JSFA66>3.0.CO;2-B

[38] Jiratanan, T. and Liu, R.H. (2004) Antioxidant Activity of Processed Table Beets (Beta vulgaris var, conditiva) and Green Beans (Phaseolus vulgaris L.). Journal of Agricultural and Food Chemistry, 52, 2659-2670. http://dx.doi.org/10.1021/jf034861d

[39] Asami, D.K., Hong, Y.J., Barrett, D.M. and Mitchell, A.E. (2003) Processing-Induced Changes in Total Phenolics and Procyanidins in Clingstone Peaches. Journal of the Science of Food and Agriculture, 83, 56-63. http://dx.doi.org/10.1002/jsfa.1275

[40] Cano, M.P. and de Ancos, B. (1994) Carotenoid and Carotenoid Ester Composition in Mango Fruit as Influenced by Processing Method. Journal of Agricultural and Food Chemistry, 42, 2737-2742. http://dx.doi.org/10.1021/jf00048a017 
[41] Cano, M.P., de Ancos, B., Lobo, G. and Monreal, M. (1996) Effects of Freezing and Canning of Papaya Slices on Their Carotenoid Composition. Zeitschrift für Lebensmittel-Untersuchung und Forschung, 202, 279-284. http://dx.doi.org/10.1007/BF01206097

[42] Cecchi, H.M. and Rodriguez-Amaya, D.B. (1981) Carotenoid Composition and Vitamin A Value of Fresh and Pasteurized Cashew-Apple (Anacardium occidentale L.) Juice. Journal of Food Science, 46, 147-149.

[43] Reddy, N.N. and Sistrunk, W.A. (1980) Effect of Cultivar, Size, Storage, and Cooking Method on Carbohydrates and Some Nutrients of Sweet Potatoes. Journal of Food Science, 45, 682-684. http://dx.doi.org/10.1111/j.1365-2621.1980.tb04131.x

[44] Bechoff, A., Dufour, D., Dhuique-Mayer, C., Marouzé, C., Reynes, M. and Westby, A. (2009) Effect of Hot Air, Solar and Sun Drying Treatments on Provitamin A Retention in Orange-Fleshed Sweetpotato. Journal of Food Engineering, 92, 164-171. http://dx.doi.org/10.1016/j.jfoodeng.2008.10.034

[45] Amiot-Carlin, M.J., Caillavet, F., Causse, M., Combris, P., Dallongeville, J., Padilla, M. and Soler, L.G. (2007) Les fruits et légumes dans l'alimentation, Enjeux et déterminants de la consommation. Expertise Scientifique Collective, 80, 26-32.

[46] Martínez, S., López, M., González-Raurich, M. and Bernardo Alvarez, A. (2005) The Effects of Ripening Stage and Processing Systems on Vitamin C Content in Sweet Peppers (Capsicum annuum L.). International Journal of Food Sciences and Nutrition, 56, 45-51. http://dx.doi.org/10.1080/09637480500081936

[47] Lim, Y.Y., Lim, T.T. and Tee, J.J. (2007) Antioxidant Properties of Several Tropical Fruits: A Comparative Study. Food Chemistry, 103, 1003-1008. http://dx.doi.org/10.1016/j.foodchem.2006.08.038

[48] Rufino, M.D.S.M., Alves, R.E., de Brito, E.S., Pérez-Jiménez, J., Saura-Calixto, F. and Mancini-Filho, J. (2010) Bioactive Compounds and Antioxidant Capacities of 18 Non-Traditional Tropical Fruits from Brazil. Food Chemistry, 121, 996-1002. http://dx.doi.org/10.1016/j.foodchem.2010.01.037

[49] Sian, N.K. and Ishak, S. (1991) Carotenoid and Anthocyanin Contents of Papaya and Pineapple: Influence of Blanching and Predrying Treatments. Food Chemistry, 39, 175-185. http://dx.doi.org/10.1016/0308-8146(91)90158-K

[50] Makris, D.P. and Rossiter, J.T. (2001) Domestic Processing of Onion Bulbs (Allium cepa) and Asparagus Spears (Asparagus officinalis): Effect on Flavonol Content and Antioxidant Status. Journal of Agricultural and Food Chemistry, 49, 3216-3222. http://dx.doi.org/10.1021/jf001497z

[51] Sahlin, E., Savage, G.P. and Lister, C.E. (2004) Investigation of the Antioxidant Properties of Tomatoes after Processing. Journal of Food Composition and Analysis, 17, 635-647. http://dx.doi.org/10.1016/j.jfca.2003.10.003

[52] Miglio, C., Chiavaro, E., Visconti, A., Fogliano, V. and Pellegrini, N. (2007) Effects of Different Cooking Methods on Nutritional and Physicochemical Characteristics of Selected Vegetables. Journal of Agricultural and Food Chemistry, 56, 139-147. http://dx.doi.org/10.1021/jf072304b

[53] Caris, C. and Amiot, M.J. (1999) Polyphénols et caroténoïdes, des substances du métabolisme secondaire des végétaux aux propriétés antioxydantes: Aspects technologiques et intérêts pour une nutrition préventive. Bulletin du Centre Technique de la Conservation des Produits Agricoles, 29, 2-6.

[54] Rickman, J.C., Barrett, D.M. and Bruhn, C.M. (2007) Nutritional Comparison of Fresh, Frozen and Canned Fruits and Vegetables. Part 1. Vitamins C and B and Phenolic Compounds. Journal of the Science of Food and Agriculture, 87, 930-944. http://dx.doi.org/10.1002/jsfa.2825 